\title{
Liat Kozma
}

\section{SEXOLOGY IN THE YISHUV: THE RISE AND DECLINE OF SEXUAL CONSULTATION IN TEL AVIV, 1930-39}

This article examines the assimilation of sexology and sexual reform in the Yishuv of the 1930s. Prominent German sexologists visited Palestine, texts they authored were translated to Hebrew and Yiddish, and members of the Yishuv community traveled to central Europe to learn sexual-reform ideas. In 1931 and 1932, three consultation centers were opened in Tel Aviv, accompanied by Q\&A columns in the general and medical press. In these centers and columns, men and women consulted medical doctors on contraception, impotence, abortions, and the everyday of heterosexual life. This short-lived experience was inspired by similar European experiences, especially in Weimar Germany and Bolshevik Russia. The 1930s discourse on sexuality was sometimes compatible with mainstream Zionist ideology and sometimes at odds with it. It came to an end during the last years of the decade, following the Arab Revolt, the Holocaust, and the demographic struggle over Palestine. 